\title{
ЗАГАЛЬНЕ УПРАВЛІННЯ ВЛАСНІСТЮ ЯК КАТЕГОРІЯ ЗДІЙСНЕННЯ ПРАВА ДЕРЖАВНОЇ ВЛАСНОСТІ
}

Москалюк Н. Б.

Статтю присвячено загальному управлінню власністю як категорії здійснення права державної власності. Сьогодні, за умови становлення всіх форм власності, коли змінюється характер державного управління, проводяться приватизаційні процеси в Україні, актуальним залишається питання дослідження процесу та особливостей управління державною власністю. Зокрема, проблема зміни форми власності з державної на приватну, і навпаки, говорить про необхідність удосконалення засад управління державною власністю, включення до його механізму функцій, які пов'язані з оптимізацією використання об'єктів державної власності.

У статmі автор вказує на доцільність уточнення складу і структури державного майна, визначення основних цілей та принципів його використання, формулювання критеріїв та засад ефективності управління. Саме ефективність управління, на думку автора, потребує детального дослідження та розроблення нових підходів і методів удосконалення.

У ході проведеного дослідження автором пропонується деталізований перелік основних напрямів підвищення ефективності управління об'єктами права державної власності.

Ключові слова: управління власністю, державна власність, здійснення права власності, об'єкти державної власності.

Статья посвящена общему управлению собственностью как категории осуществления права государственной собственности. Сегодня, в условиях становления всех форм собственности, когда меняется характер государственного управления, проводятся приватизационные процессы в Украине, актуальным остается вопрос исследования процесса и особенностей управления государственной собственностью. В частности, проблема изменения формы собственности с государственной на частную, и наоборот, говорит о необходимости совершенствования основ управления государственной собственностью, включение в его механизм функций, связанных с оптимизацией использования объектов государственной собственности.

В статье автор указывает на челесообразность уточнения состава и структуры государственного имущества, определение основных целей и принципов его использования, формулировку критериев и принципов эффективности управления. Именно эффективность управления, по мнению автора, требует детального исследования и разработки новых подходов и методов совершенствования.

В ходе проведенного исследования автором предлага ется детализированный перечень основных направлений повышения эффективности управления объектами права государственной собственности.

Ключевые слова: управление собственностью, государственная собственность, осуществление права собственности, объекты государственной собственности.

(c) Москалюк Н. Б., 2020
Moscaliuk N. B. General property management as a category of state property right exercising

The article is dedicated to the general management of property as a category of the state property right exercising. Today, with the formation of all forms of ownership, when the nature of public administration changes, privatization processes are carried out in Ukraine, the issue of studying the process and features of public property management remains relevant. In particular, the problem of changing the form of ownership from state to private, and vice versa, suggests the need to improve the principles of state property management, the inclusion in its mechanism of functions related to optimizing the use of state property.

In the article the author points out the expediency of clarifying the composition and structure of state property, defining the main goals and principles of its use, formulating criteria and principles of management efficiency. According to the author the effectiveness of management requires detailed research and development of new approaches and methods of improvement.

In the course of the study, the author proposes a detailed list of the main areas of improving the management of state property:

1. application of strategic and program-targeted management of state-owned objects; establishing the main tasks of such management for each object; optimization of the number of management facilities and return of illegally expropriated property to state ownership;

2. conducting an inventory of state-owned objects and maintaining a register of these objects; promoting transparency and information support of the management process and the creation of appropriate software and hardware with a single data format;

3. formation of public-private partnership in the economic and social sphere;

4. updating existing management methods, for example, formation of an effective system for monitoring management processes, analysis of the effectiveness of statistical and tax data;

5. attracting investors to increase the efficiency of stateowned enterprises through corporatization;

6. creating conditions for the growing role of business in solving social problems, as well as ensuring the formation of a competitive environment;

7. strengthening state control and responsibility of executive bodies in the management of state property; providing training for specialists in the field of public administration;

8. increase of control over the technical condition and operation of state-owned objects;

9. Improving the legal regulation of state property management and defining at the legislative level the main powers of the participants in these relations.

Key words: property management, state property, exercise of property rights, objects of state property.

Постановка проблеми та їі актуальність. Конституція України визначила основи правового регулювання відносин державної власності й управління нею. У ній містяться фундаментальні положення щодо місця державної 
власності серед інших форм власності, які визнаються рівноправними. Варто зазначити, що згідно з Основним Законом держава Україна має у власності значний обсяг майна, яке використовується ії органами й посадовими особами для виконання їі основних завдань та функцій. Управління державною власністю здійснюється відповідними, визначеними законом, суб'єктами з метою реалізації загальносуспільних потреб та інтересів.

Сьогодні, за умови становлення всіх форм власності, коли змінюється характер державного управління, проводяться приватизаційні процеси в Україні, актуальним залишається питання дослідження процесу та особливостей управління державною власністю. Зокрема, проблема зміни форми власності з державної на приватну, i навпаки, говорить про необхідність удосконалення засад управління державною власністю, включення до його механізму функцій, які пов'язані з оптимізацією використання об'єктів державної власності.

Окрім того, актуальності набувають завдання уточнення структури і складу державного майна, визначення основних цілей та принципів його використання, формулювання критеріїв та засад ефективності управління, що потребує детального дослідження та розроблення нових підходів і методів до вдосконалення процесу управління державним майном, що відповідали б соціально-економічній ситуації в Україні.

Аналіз останніх досліджень і публікацій. Варто зазначити, що увага науковців частково приділяється питанню організації управління державною власністю. Зокрема, дану тему вивчали: Е. Балацький, Р. Биков, Є. Білокур, С. Кочеткова, О. Кравчук, Б. Пасхавер, В. Пількевич, В. Савченко, М. Шкільняк тощо. Адміністративно-правовий аспект управління досліджували: О. Альохін, С. Братусь, А. Венедиктов, Ю. Козлов, В. Опришко та ін. Проте потребує детального вивчення питання управління власністю в контексті здійснення права державної власності з позиції цивільного права.

Метою статті $\epsilon$ аналіз управління власністю як категорії здійснення права державної власності, визначення недоліків правого регулювання даного питання та пропозицій удосконалення механізму управління об'єктами права державної власності в Україні.

Виклад основного матеріалу. Перш ніж перейти до безпосереднього висвітлення питання загального управління власністю, проаналізуємо понятійно-категоріальний апарат, що застосовується в даному питанні.

Отже, доктринальний підхід до розуміння управління державною власністю зводиться до розуміння його як нормотворчої та організаційно-розпорядчої діяльності органів виконавчої влади та інших уповноважених суб'єктів з метою владно-організуючого впливу на суспільні відносини щодо володіння, користування і розпорядження майном, що належить державі (об'єктами права державної власності)» [1, с. 371].

На думку $Є . І$. Білокур, «порівняно зі змістом державного управління необхідно вказати на те, що управління об'єктами державної власності не $\epsilon$ певним видом загальнородового поняття «управління», а $\epsilon$ частиною змісту державної управлінської діяльності <...> Зміст управління об'єктами державної власності потрібно усвідомлювати $з$ використанням норм цивільного та господарського законодавства» [2].

І. Гуськова стверджує, що «все різноманіття наукових підходів до визначення поняття «управління» зумовлене багатогранністю і складністю цього явища, яке дуже важко представити одним визначенням. Тому представники різних наукових шкіл бачать це явище по-різному i формулюють визначення «управління» по-своєму, розставляючи акценти на тих або інших його аспектах» [3, с. 162].

У Конституції України містяться основні положення щодо місця державної власності серед інших форм власності. У ст. 13 закріплено, що право державної власності від імені Українського народу здійснюють органи державної влади [4]. Схожу норму містить і цК України. Так, згідно зі ст. 326 цК України від імені та в інтересах держави Україна право власності здійснюють, відповідно, органи державної влади [5]. До них належить Президент України, що виступає від імені держави в різних правовідносинах, зокрема, здійснює право державної власності. Верховна Рада України також здійснює право державної власності, адже вона затверджує державний бюджет, а також виконує інші повноваження у даній сфері, відповідно до ст. 85 Конституції України.

Згідно з п. 5 ст. 116 Конституції України [4] та ст. 20 Закону України «Про Кабінет Міністрів України» [6], державне управління $€$ одним 3 основних завдань Уряду, що полягає в управлінні об'єктами державної власності, в тому числі корпоративними правами, а також у делегуванні в установленому законом порядку окремих повноважень щодо управління зазначеними об'єктами міністерствам, іншим центральним органам виконавчої влади, місцевим державним адміністраціям та відповідним суб'єктам господарювання, забезпечення розроблення і виконання державних програм приватизації; подання Верховній Раді України пропозицій стосовно визначення переліку об'єктів права державної власності, що не підлягають приватизації.

Закон України «Про управління об'єктами державної власності» від 21 вересня 2006 року № 185-V дав визначення поняття управління й передбачив систему суб'єктів і об'єктів управління. У ст. 1 цього Закону було встановлено, що управління об'єктами державної власності здійснюється не лише Кабінетом Міністрів України, а й уповноваженими ним органами та іншими суб'єктами, визначеними цим Законом [7]. Зокрема, це Фонд державного майна України, міністерства та відомства, інші державні органи. До компетенції даних органів входить створення та припинення державних підприємств і установ, а також контроль за їхньою діяльністю, надання дозволу щодо відчуження ними основних засобів виробництва. Основні повноваження цих суб'єктів визначені в ст. 5-10 Закону «Про управління об'єктами державної власності».

Окрім цього, для кожної з даних категорій суб'єктів законами визначено права та обов'язки, які мають важливе значення під час здійснення їхніх повноважень. Так, окремими законами регулюється порядок здійснення права власності на об'єкти, які закріплені за навчальними та культурними закладами. Це Закони «Про музеї та музейну справу» від 29 червня 1995 року № 249/95-ВР, «Про вищу освіту» від 1 липня 2014 року № 1556-VII тощо.

Виходячи з норм чинного законодавства України, зміст права власності включає права володіння, користування та розпоряджання майном (ст. 316 Цивільного Кодексу, далі - ЦК). Згідно зі ст. 326 ЦКУ до об'єктів права державної власності відноситься майно, в тому 
числі грошові кошти, яке належить державі Україна [5]. Коло таких об'єктів не обмежене.

Здійснення права власності передбачається у ст. ст. 316, 319 цК, відповідно до яких особа здійснює право на майно:

а) відповідно до закону;

б) за своєю волею;

в) незалежно від волі іншої особи;

г) на власний розсуд;

д) шляхом реалізації власником правомочностей володіти, користуватися та розпоряджатися своїм майном;

е) вчиняючи щодо свого майна будь-які дії, які не суперечать закону;

є) використовуючи своє майно для підприємницької діяльності (ст. 320 цК) [8, с. 427].

Гарантіями здійснення такого права власності насамперед $\epsilon$ забезпечення всім рівних умов здійснення прав (ч. 3 ст. 319 Цивільного кодексу) та невтручання держави у здійснення права власності (ч. 6 ст. 319 Цивільного кодексу), а також непорушність самого права власності (ст. 321 цК) [5]. Окрім того, відбувається таке здійснення права власності або прямо або опосередковано. Пряме здійснення характерно для приватних власників, опосередковане - для народу України, територіальних громад, що здійснюють свої права через уповноважених осіб. Допускається і поєднання обох способів.

Отже, під час управління державною власністю суб'єкт, що здійснює функцію державного управління, $\epsilon$ суб'єктом, який наділений господарською компетенцією і здійснює організаційно-господарські повноваження. Управління державною власністю здійснюється відповідними суб'єктами з метою надання державою суспільних послуг та забезпечення інтересів. Здійснюючи зазначені функції, органи державної влади діють не як суб'єкти права власності, а як представники останньої: вони діють не від власного імені й не у своєму інтересі, а від імені й в інтересі держави в цілому, носієм суверенітету та єдиним джерелом влади в якій $\epsilon$ ї̈ народ [9].

Особливістю державної власності також $\epsilon$ те, що це власність усіх громадян у масштабі держави без наявності в них якої-небудь фіксованої частки, зі специфічними умовами вступу у володіння і втратою останнього. Ще однією специфічною рисою великогрупової, як іiі називає І. Гуськова, власності $\epsilon$ спосіб управління та розпорядження нею. 3 правової точки зору тут чітко формулюється загальний принцип: державна власність це власність, якою володіє весь народ, а розпоряджається держава за допомогою своїх органів [3, с. 165].

Управління суб'єктами державного управління може здійснюватися по-різному, зокрема: використання державного майна з метою отримання корисних властивостей; оренда державного майна; ухвалення рішення про відчуження державного майна, його заставу, списання, передачу до комунальної або приватної власності тощо; господарське відання чи оперативне управління державним майном.

Досліджуючи процес загального управління власністю на практиці, нами встановлено, що з 2002 по 2012 рр. в Україні не приймалися нові програми приватизації, а також не було розроблено стратегії розвитку управління державним майном, що до певної міри свідчить про законодавчу невизначеність щодо приватизації об'єктів державної власності та існування ризиків відчуження такого майна за тіньовими схемами. Лише
В Державній програмі приватизації на 2012-2014 pp. визначено мету, шляхи, способи, заходи і завдання приватизації державного майна [10].

Варто відзначити, що натепер в Україні існує більше 80 суб'єктів управління об' єктами державної власності. Їм підпорядковано більше ніж 3500 підприємств, більшість $з$ яких не здійснюють господарської діяльності [11]. Негативним $€$ той аспект, що значна кількість державних підприємств $є$ збитковою і виступає потенційним джерелом ризиків. Також через низьку якість контролю і незадовільний рівень прозорості їхньої діяльності державні підприємства у великій мірі $є$ джерелом корупційних ризиків і збитків держави. Тому основною метою реформи державних підприємств $\epsilon$ підвищення ефективності їхньої діяльності, а не приватизація як єдиний шлях виходу із ситуації, що склалась.

Варто зазначити, що не лише на практиці, а й у законодавчому регулюванні управління державною власністю існують вагомі прогалини, зони «слабкого» регулювання. Зокрема, в Україні управління державною власністю розосереджене між великою кількістю органів управління виконавчої, законодавчої, судової гілок влади та інших суб'єктів. Неврегульованість у законодавстві ряду адміністративних процедур у сфері управління об'єктами державної власності призводить до ї хаотичної передачі, безконтрольного використання державного майна, а подекуди і до його втрати. Обмеженість доступу до інформації про діяльність державних підприємств, установ, організацій призводить до того, що держава не має належної повної інформації про нерухомість, земельні ділянки, транспортні засоби й інше майно, яке ій належить та закріплене за цими підприємствами. Враховуючи недосконалість нормативно-правової бази у сфері управління, що довгий час гальмувала приватизаційні процеси, велике недофінансування заходів щодо управління державною власністю спричинило зниження попиту на дані об'єкти та суттєве недоотримання коштів до державного бюджету.

Після перемоги революції гідності уряд прагне вдосконалити й механізм корпоративного управління державним сектором економіки. 3 цією метою підготовлено 12 законопроектів щодо внесення змін до Закону України «Про управління об'єктами державної власності», які були прийняті Верховною Радою України. Відтепер керівників підприємств державного сектору економіки призначають наглядові ради цих підприємств, до складу яких, крім державних службовців, обираються на конкурсних засадах незалежні члени, кількість яких повинна становити більшість членів наглядової ради. Проте станом натепер ситуація з ефективністю управління об'єктами державної власності кардинально так і не змінилася. 3 одного боку, це відбувається через невиконання нових вимог закону, а з іншого - через недоліки формулювання самих нових вимог закону. Покращення управління в державному секторі економіки так і не спостерігається, а відповідальність за це стає ще більш розмитою між Верховною Радою, Урядом, Мінекономрозвитку та галузевими міністерствами [11].

Варто відзначити, що сьогодні в системі державної влади України відбуваються досить складні та суперечливі процеси, які спрямовані на реформування неефективної системи управління. Очевидно, що дана система потребує глобальної модернізації, адже це дало би змогу створити надійну, збалансовану, ефек- 
тивну систему державного управління, яка б відповідала світовим стандартам. Сучасні здобутки держав-членів $\epsilon C \in$ прикладом того, чого можна досягнути за короткий історичний проміжок часу. Успіхи країн Євросоюзу показують, і чого можна не досягти, якщо сповідувати постійну невизначеність у пріоритетах щодо реалізації державного управління.

Для запровадження європейської моделі державного управління в Україні, на думку Ю.В. Ковбасюка, потрібно використовувати алгоритм механізму дослідження стану і напрямів удосконалення державного управління: 1) вивчення теоретичних і практичних аспектів у динаміці; 2) вивчення зарубіжного досвіду й аналіз можливості його використання; 3) аналіз впливу на ефективність діяльності; 4) визначення основних проблем; 5) розроблення пропозицій щодо удосконалення; 6) розроблення проектів нормативних документів, спрямованих на реалізацію розроблених пропозицій [11].

Отже, основним напрямом модернізації управління державною власністю має стати реформування засад діяльності органів державної влади України, яка має бути побудована на принципах надійності й можливості прогнозування, відкритості та прозорості, відповідальності, а також ефективності та результативності. Окрім того, управління об'єктами державної власності $\epsilon$ сферою, яка вимагає якісної правової регламентації та чіткого і детального визначення повноважень усіх учасників даних відносин.

Висновки. У зв'язку із зазначеним вважаємо за необхідне окреслити основні напрями підвищення ефективності управління об'єктами права державної власності в Україні:

1) застосування стратегічного i програмно-цільового управління об'єктами державної власності; встановлення основних завдань такого управління для кожного об'єкта; оптимізація кількості об'єктів управління та повернення незаконно відчуженого майна до державної власності;

2) проведення інвентаризації об'єктів державної власності та ефективне ведення реєстру даних об'єктів; сприяння прозорості й інформаційному забезпеченню процесу управління та створення відповідного програмно-технічного забезпечення з єдиним форматом даних;

3) формування державно-приватного партнерства в економіко-соціальній сфері;

4) оновлення існуючих методів управління, наприклад: формування ефективної системи моніторингу процесів управління, аналізу ефективності застосування статистичних і податкових даних, застосування кращого іноземного досвіду управління об'єктами державної власності;

5) залучення інвесторів з метою підвищення ефективності діяльності держпідприємств шляхом корпоратизації;

6) створення умов для зростання ролі бізнесу у вирішенні соціальних проблем, а також забезпечення формування конкурентного середовища;

7) посилення державного контролю та відповідальності виконавчих органів під час здійснення управління об'єктами державної власності; забезпечення підготовки спеціалістів у сфері державного управління за кращими світовими стандартами;

8) підвищення контролю за технічним станом та експлуатацією об'єктів державної власності;
Проблеми цивільного та господарського права

9) вдосконалення правового регулювання управління об'єктами державної власності та визначення на законодавчому рівні основних повноважень учасників даних відносин.

Саме означені напрями підвищення ефективності управління об'єктами права державної власності, на нашу думку, допоможуть якісно виконувати основні завдання державної власності - створення та фінансування галузей, необхідних для процесу економічного зростання; забезпечення вирівнювання економічного циклу; гарантування національної безпеки та стабільності в державі; підтримка зайнятості населення тощо.

\section{Література}

1. Кравчук 0.0. Управління державною власністю: адміністративно-правові засади : монографія. Київ : НТУу «КП।», 2013. 444 c.

2. Білокур Є.І. Управління об'єктами державної власності як складова змісту державно-управлінської діяльності. Вісник Чернівецького факультету Національного університету «Одеська юридична академія». 2015. Вип. 2. С. 35-45. URL: http://nbuv.gov.ua/UJRN/vchfo_2015_2_6

3. Гуськова І. Особливості управління комунальною власністю як специфічною формою групової власності. URL: http://www.kbuapa.kharkov.ua/e-book/putp/2012-4/ doc/3/08.pdf

4. Конституція України від 28 червня 1996 р. URL: https: / /zakon.rada.gov.ua/laws/show/254\%D0\%BA/96\%D0\%B2\%D1\%80

5. Цивільний кодекс України від 16 січня 2003 р. URL: https://zakon.rada.gov.ua/laws/show/435-15

6. Про Кабінет Міністрів України : Закон України від 27 лютого 2014 р. № 794-VII. URL:https: / /zakon.rada.gov.ua/ laws/show/794-18

7. Про управління об'єктами державної власності : Закон України від 21 вересня 2006 р. № 185-V. URL: http://zakon.rada.gov.ua/laws/show/185-16

8. Цивільне право : підручник : у 2 т. / під. ред. В.І. Борисової, І.В. Спасибо-Фатєєвої, В.Л. Яроцького. Харків : Право, 2011. Т. 1.656 с.

9. Харитонова О.І. До питання про характеристику права державної власності. URL: http://www.apdp.in.ua/ v33/49.pdf

10. Биков Р.Ю. Механізми управління державним майном в Україні : автореф. дис. ... канд. наук з держ. упр. : 25.00.02. Київ, 2010. 20 с. URL: https://www.researchgate. net/publication/322721920_MEHANIZMI_UPRAVLINNA_ DERZAVNIM_MAJNOM_V_UKRAINI

11. Щербина М. Чи покращиться управління державним майном? 2018. URL: https://nv.ua/ukr/biz/experts/chipokrashchitsya-upravlinnya-derzhavnim-maynom-2473115.html

12. Модернізація державного управління та європейська інтеграція України : наук. доп. / за заг. ред. Ю.В. Ковбасюка. Київ : НАДУ, 2013. 120 с.

13. Савченко В.Ф. Державне регулювання відносин власності у ринковій економіці. Науковий вісник Полісся. 2015. Вип. 3. С. 9-18.

14. Плакіда В.Т. Управління державною власністю: світовий досвід та реалії України : монографія. Донецьк, 2010. 400 C.

15. Пількевич В.Л. Організаційно-правове забезпечення управління державним майном в Україні : дис. ... канд. юрид. наук : 12.00.07. Київ, 2006. 220 с.

Москалюк Н. Б., кандидат юридичних наук, доцент, завідувач кафедри безпеки, правоохоронної діяльності та фінансових розслідувань Тернопільського національного економічного університету 